\title{
Phoresy of astigmatic mites on ticks and fleas in Poland
}

\author{
GRZEGORZ KARBOWIAK ${ }^{1}$, KRZYSZTOF SOLARZ ${ }^{2}$, MAREK ASMAN ${ }^{2}$, \\ ZBIGNIEW WRÓBLEWSKI ${ }^{3}$, KATERYNA SLIVINSKA ${ }^{4}$ and JOANNA WERSZKO ${ }^{1}$ \\ ${ }^{1}$ Witold Stefański Institute of Parasitology, Polish Academy of Sciences, Twarda 51/55, \\ 00-818 Warsaw, Poland \\ ${ }^{2}$ Department of Parasitology, Medical University of Silesia in Katowice, Jedności 8, \\ 41-218 Sosnowiec, Poland \\ ${ }^{3}$ Veterinary Health Centre, Mickiewicza 41, 12-200 Pisz, Poland \\ ${ }^{4}$ I.I. Schmalhausen Institute of Zoology, National Academy of Sciences of Ukraine, \\ B. Khmelnytskogo 15, $01601 \mathrm{Kiev}$, Ukraine \\ Corresponding author: Grzegorz Karbowiak, grzgrz@twarda.pan.pl
}

(Received on 3 March 2013; Accepted on 28 August 2013)

\begin{abstract}
Phoresy is an association in which a small animal clings to a larger one exclusively for transportation. We searched for phoretic mites on fleas and ticks of small mammals. A total of 169 fleas of 7 species were collected in the Białowieża Forest (E Poland) and in Kosewo Górne (NE Poland) in July and August in 2007 and 2008. Moreover, 20 nymphs and 12 females of Ixodes hexagonus (Leach, 1815) were collected in the beaver farm of the Research Station of Polish Academy of Sciences in Popielno (NE Poland) in April and May 2009. Phoretic mites were found on 26 fleas (15.4\%) of the following species: $\mathrm{Me}$ gabothris walkeri (Rothschild, 1902), Megabothris turbidus (Rothschild, 1909), Ctenophthalmus agyrtes (Heller, 1896), and Hystrichopsylla orientalis (Smit, 1956). The mites were located mainly on abdominal sternites. Among ticks, only one female was positive for mites, whose larvae (hypopi) were found on its legs. A total of 6 species of mites were identified. On I. hexagonus, we found Acarus farris (Oudemans, 1905) (53 larvae), Acarus siro (L., 1758) (2 larvae), Acarus nidicolous (Griffiths, 1970) (1 larva), Caloglyphus rhizoglyphoides (Zachvatkin, 1937) (1 larva), and Histiostoma feroniarum (Dufour, 1904) (28 larvae), whereas on fleas, 79 larvae of Acarus nidicolous, 1 male of Tyrophagus putrescentiae (Schrank, 1781), and 1 unidentified trombiculid larva. The last 2 mite specimens were found on M. turbidus. This is the first report on phoretic association of the flea $H$. orientalis and the tick $I$. hexagonus with mites.
\end{abstract}

Keywords: fleas, Astigmatina, phoresy, hypopi, Ixodes hexagonus

\section{INTRODUCTION}

Phoresy is a kind of symbiotic relationship, in which one organism transports on the surface of its body another organism of a different species. This phenomenon is known among many animals, but primarily among arthropods. It is a common way of passive dispersal among mites, where they "hitch a ride" on larger animals, usually 
insects or other arthropods. Usually they cease or otherwise alter normal behaviours (e.g. feeding, reproduction, movement) until some cue elicits their departure from the animal and the resumption of normal behaviour (COMBEs 1995; BoczeK \& BtASZAK 2005).

The most spectacular diversity of phoretic associations among animals occurs in mites (Acari) (Houck \& O'CONNOR 1991). Some mites hold on to their phoretic carriers with specialized structures (e.g. the anal pedicel in Uropodina; modified legs I in phoretomorphic Pygmephoridae; a specialized tooth on the chelicerae of many Macrocheles spp.), but others simply use their feet or grip a seta with unmodified mouthparts. Phoresy usually results in dispersal but may result in reaggregation, especially for mites using highly specialized habitats (e.g. pitcher plants and other phytotelmata). Phoretic relationships may be highly host-specific, very general, or anywhere in between, depending on the species (COMBEs 1995). Only one developmental stage is usually specialized for dispersal in mites, and the degree of specialization of that stage can be classified into unspecialized homeomorphs, specialized homeomorphs, and facultative heteromorphs, such as hypopi in Astigmata (Houck \& O'CONNOR 1991; BOCZEK \& BŁASZAK 2005). These heteromorphs are characterized by a rudimentary gnathosoma, the absence of a mouth and a hollow gut, extensive sclerotization, and a caudoventral attachment organ. The frequency of the induction of the heteromorphic deutonymph (hypopus) varies among taxa. Phoresy is a common phenomenon in the life cycle of free-living astigmatic mites and has long been controversial with regard to origin and significance. Astigmatic mites have phoretic associations with a wide diversity of mammal groups, including rats, mice, hamsters, squirrels, chipmunks, marmots, bats, primates, badgers, armadillos, shrews, other insectivores, and opossums (WhITAKER et al. 1983; HoucK \& O'CONNOR 1991; BALASHOv 2006a, b; WhITAKER et al. 2007). Many species of these mites are common nest associates of wild mammals throughout the world, and therefore their hypopi are found on fleas. There is a potential for interspecific host transfer between taxa (e.g. mammals, birds, and fleas) because of trophic or habitat preferences. In some taxa of astigmatic mites, parasitism on birds seems to have evolved from phoresy, as hypopi acquired the ability to absorb the liquid nutrients from hair follicles and subcutaneous tissues through the cuticle (BALASHOv 2006a).

During earlier studies on fleas and ticks associated with small mammals, we found hypopi of Astigmata mites on fleas and a tick. The goal of this study was to identify the phoretic mite species associated with them and to analyse them quantitatively.

\section{MATERIAL AND METHODS}

A total of 169 fleas were examined for occurrence of phoretic mites. The research on fleas was conducted in the Białowieża Forest (eastern Poland) and in Kosewo Górne (Mazurian Lakeland, north-eastern Poland) in July-August in 2007 and 2008. In the Białowieża Forest, 7 flea species were collected from root voles Microtus oeconomus (Pallas, 1776): Megabothris walkeri (Rothschild, 1902), M. turbidus (Rothschild, 1909), Hystrichopsylla orientalis (Smit, 1956), Ctenophthalmus agyrtes 
(Heller, 1896), C. uncinatus (Wagner, 1898), Palaeopsylla soricis (Dale, 1878), and Peromyscopsylla bidentata (Kolenati, 1883). In Kosewo Górne, 6 species of fleas were isolated from bank voles Myodes glareolus (Schreber, 1780) and yellow-necked mice Apodemus flavicollis (Melchior, 1834): M. turbidus, H. orientalis, Ctenophthalmus assimilis (Taschenberg, 1880), C. agyrtes, C. uncinatus, and P. bidentata. All fleas were collected from mammals caught in live traps. Phoretic mites occurring on these fleas were searched for under a light microscope, using magnifications of $\times 2$ and $\times 10$.

Additionally, 20 nymphs and 12 females of Ixodes hexagonus (Leach, 1815) were collected by hand in the beaver farm of the Research Station of the Polish Academy of Sciences in Popielno (north-eastern Poland) in April-May 2009, from beaver fur. All the ticks were examined for occurrence of phoretic mites, but only one female of I. hexagonus carried them.

All mite specimens collected were examined using differential interference contrast (Nomarski DIC) under a light microscope (Zeiss Axioskope 2 plus) and phase contrast optics under another light microscope (Olympus $\mathrm{CH} 40$ ). Mite species were identified using descriptions of taxa (Bregetova et al. 1955; Bregetova 1956; Griffiths 1970; FAIN \& BEAUCOURNU 1973), identification keys or other publications (GILYAROV \& Krivolutskij 1975; Hughes 1976; Britt \& Molyneux 1983; Fain \& Beaucournu 1993; Krantz \& WaLter 2009), and an unpublished document by O'Connor (not for publication or distribution without permission). Moreover, all collected hypopi of Acarus nidicolous were analysed for more exact differentiation from $A$. avicolus (Tables 2 and 3 ).

A total of 6 diagnostic characters were measured in each specimen of $A$. nidicolous: length and width of idiosoma, length of tarsi IV, and distances between setae $(\mathrm{d} 2-\mathrm{d} 2, \mathrm{~d} 1-\mathrm{d} 2$, and 15-15). All measurements (in $\mu \mathrm{m})$ were based on slide-mounted specimens examined using differential interference contrast (Nomarski DIC) under the light microscope (Zeiss Axioskope 2 plus). Photographs were taken with the digital video camera (Sony Exwave HAD). A modular image processing and analysis system (Axio-Vision version 3.0, Zeiss) was used to allow accurate measurements. All data analyses were performed using CSS-Statistica for Windows version 9.

\section{RESULTS}

A total of 81 mites were collected from fleas (Table 1). Hypopi of astigmatic mites were found on 26 fleas (15.4\% of the total catch), on their abdominal sternites. The mites were present on 3 flea species collected in the Białowieża Forest: M. walkeri (on 5 fleas out of 30 collected, 16.7\%), C. agyrtes (on 1 out of 27 fleas collected, 3.7\%), and $H$. orientalis (a single flea collected and positive for mites). On other species of fleas examined, hypopi and other developmental stages of mites were absent (Table 1). Phoretic mites were also detected on 3 flea species collected in Kosewo Górne: M. turbidus (on 7 out of 22 fleas collected, 31.8\%), H. orientalis (on 2 out of 9 fleas collected, 22.2\%), and C. agyrtes (on 3 out of 15 fleas collected, 20\%) (Table 1). From 1 to 3 mites were present on a single flea. Moreover, 85 hypopi were collected from the female of $I$. hexagonus (Table 4), mainly from its legs. 
Table 1. Numbers of fleas examined and with mites in each location

\begin{tabular}{lrrrr}
\hline \multirow{2}{*}{ Flea species } & \multicolumn{2}{c}{ Fleas from Kosewo Górne } & \multicolumn{2}{c}{ Fleas from Białowieża } \\
\cline { 2 - 5 } & examined & with mites & examined & with mites \\
\hline Megabothris walkeri & 0 & 0 & 30 & 5 \\
Megabothris turbidus & 22 & 7 & 14 & 7 \\
Hystrichopsylla orientalis & 9 & 2 & 1 & 1 \\
Ctenophthalmus agyrtes & 15 & 3 & 27 & 1 \\
Ctenophthalmus uncinatus & 29 & 0 & 0 & 0 \\
Palaeopsylla soricis & 9 & 0 & 4 & 0 \\
Peromyscopsylla bidentata & 2 & 0 & 3 & 0 \\
\hline
\end{tabular}

The analysis of diagnostic characters (Table 2) made it possible not only to estimate the range of variation but mainly to assess the correctness of identification of all collected hypopi of A. nidicolous (Tables 2 and 3 ) and other hypopi of this genus.

Table 2. Variability of measurements (in $\mu \mathrm{m}$ ) of the main diagnostic characters of Acarus nidicolous hypopi collected from the examined tick and fleas

\begin{tabular}{lrrr}
\hline Character & Mean \pm SD & Median & Range \\
\hline Length of idiosoma & $231.11 \pm 8.83$ & 228.97 & $218.23-243.70$ \\
Width of idiosoma & $156.51 \pm 8.64$ & 153.14 & $146.99-171.31$ \\
Length of tarsi IV & $14.75 \pm 0.39$ & 14.77 & $14.22-15.36$ \\
Distance between setae d2-d2 & $35.20 \pm 0.75$ & 35.48 & $34.35-35.77$ \\
Distance between setae d1-d2 & $27.13 \pm 1.36$ & 27.13 & $26.17-28.09$ \\
Distance between setae 15-15 & $45.28 \pm 3.47$ & 44.63 & $41.64-49.75$ \\
\hline
\end{tabular}

$\mathrm{SD}=$ standard deviation

In total, 6 species of mites were identified during the study (Table 4). The following mite species and numbers of hypopi were collected from the female tick $I$. hexagonus: Acarus farris (Oudemans, 1905) $(n=53)$, A. siro (L., 1758) $(n=2)$, Acarus nidicolous (Griffiths, 1970) $(n=1)$, Caloglyphus rhizoglyphoides (Zachvatkin, 
Table 3. Ranges of measurements (in $\mu \mathrm{m}$ ) of the main diagnostic characters of hypopi of Acarus avicolus and A. nidicolous according to Griffiths (1970) and Fain \& BEAUcournu (1972)

\begin{tabular}{lrr}
\hline Character & A. avicolus & A. nidicolous \\
\hline Length of idiosoma & $250-270$ & $220-240$ \\
Width of idiosoma & $195-204$ & $153-163$ \\
Length of tarsi IV & 19 & 15 \\
Distance of setae d2-d2 & $45-64$ & $30-40$ \\
Distance of setae d1-d2 & $20-23$ & $20-30$ \\
Distance of setae 15-15 & $50-54$ & $35-42$ \\
\hline
\end{tabular}

Table 4. Phoretic mites collected from the examined tick and fleas

\begin{tabular}{llll}
\hline \multicolumn{2}{l}{ Mites collected from Ixodes hexagonus } & \multicolumn{2}{l}{ Mites collected from fleas } \\
\hline $\begin{array}{l}\text { Astigmatina, } \\
\text { Acaridae }\end{array}$ & $\begin{array}{l}\text { Astigmatina, } \\
\text { Anoetidae }\end{array}$ & Prostigmata & $\begin{array}{l}\text { Astigmatina, } \\
\text { Acaridae }\end{array}$ \\
\hline Acarus farris (53 hypopi) & $\begin{array}{l}\text { Histiostoma } \\
\text { feroniarum } \\
\text { (28 hypopi) }\end{array}$ & $\begin{array}{l}\text { Trombiculidae } \\
\text { (1 larva) }\end{array}$ & $\begin{array}{l}\text { Acarus nidicolous } \\
\text { (79 hypopi) }\end{array}$ \\
A. siro (2 hypopi) & & $\begin{array}{l}\text { Tyrophagus } \\
\text { putrescentiae } \\
\text { (1 male) }\end{array}$ \\
A. nidicolous (1 hypopus) & & \\
Caloglyphus rhizoglyphoides & & \\
(1 hypopus) & & \\
& & & \\
\hline
\end{tabular}

1937) from the family Acaridae, Astigmatina $(n=1)$, and Histiostoma feroniarum (Dufour, 1904) from the family Anoetidae, Astigmatina $(n=28)$. Moreover, 2 species of astigmatic mites were collected from fleas: A. nidicolous (79 hypopi) and Tyrophagus putrescentiae (Schrank, 1781) from the family Acaridae, Astigmatina (1 male, on $M$. turbidus). Additionally, a single unidentified larva from the family Trombiculidae was found on the flea M. turbidus collected in the Białowieża Forest (Table 4). It should be stressed that a majority of these mites were collected from both Megabothris species.

\section{DISCUSSION}

Many authors have reported the presence of mite hypopi on arthropod parasites of mammals and birds, such as fleas (BRitT \& Molyneux 1983; WhitAKer et al. 1983, 2007; Houck \& O’Connor 1991; Fain \& Beaucournu 1993; Fain \& Galloway 
1993; Schwan 1993; Matthee et al. 2007), ticks (Dubinina \& Alekseev 1995), and gamasid mites (Mesostigmata) (DuRDEN 1986), as well as on ants and the hair of small rodents and insectivores (Pence \& WebB 1977; FAin \& Whitaker 1985; Fain 1987). Phoretic relations between fleas and mite hypopi have been reported in over 20 mite species, belonging to at least 9 genera and 3 families, mainly the Acaridae, Saproglyphidae, and Anoetidae (Astigmata) (Haitlinger 1978; Preisler et al. 1990; Houck \& O’CONNOR 1991; Boczek \& BŁaszaK 2005). Mite carriers belong to various systematic groups, but they are most common among the Coleoptera, Diptera, and Hymenoptera (Houck \& O'ConNor 1991; SzYmkowiak et al. 2007). Phoretic associations with the Siphonaptera are poorly studied (HoucK \& O'CONNOR 1991). The carrying of hypopi by Ixodida has been reported only by DuBININA \& ALEKSEEV (1995). On the other hand, phoretic associations between fleas and astigmatic mites Acarus nidicolous, A. avicolus, $A$. siro, $A$. farris, and $H$. feroniarum are not rare in France (FAIN \& BEAUCOURNU 1973) as well as between $A$. nidicolous and fleas from small mammals in the United Kingdom (BRITT \& Molyneux 1983). Hypopi of $A$. nidicolous were found on many flea species: Ctenophthalmus agyrtes, C. arvernus (Jordan, 1931), C. solutus solutus (Jordan \& Rothschild 1920), C. nobilis vulgaris (Rothschild, 1898), C. bisoctodentatus (Kolenati, 1863), Palaeopsylla minor (Dale, 1878), Nosopsyllus fasciatus (Bosc, 1800), Malareus penicilliger mustelae (Dale, 1878), M. turbidus, Hystrichopsylla talpae talpae (Curtis, 1826), and Archaeopsylla erinacei erinacei (Saupe, 1995). Hypopi of $A$. avicolus were present on fleas Ceratophyllus garei borealis (Rothschild, 1906), C. styx styx (Rothschild, 1900), Dasypsyllus gallinulae gallinulae (Dale, 1878), whereas hypopi of H. feroniarum, on Doratopsylla dasycnema (Rothschild 1897) and Ceratophyllus columbae (Gervais, 1844) (FAin \& BeAucournu 1973).

During this study, the most common mites were $A$. nidicolous on fleas and $A$. farris on $I$. hexagonus. It is evident that mites are carried mostly by the flea species being dominant in the community. M. walkeri is the most common flea on the root vole M. oeconomus (LACHMAJER \& Wegner 1956; SKURATOWICZ 1967), while M. turbidus, on other voles of the genus Microtus as well as on Myodes glareolus. Ctenophthalmus agyrtes is very common on almost all small rodents, but $H$. orientalis belongs to the dominant group of fleas in autumn (SKuratowicz 1967; Haitlinger 1983; StanKo 1988; KARBOWIAK \& WiTA 2001). Similar results, showing the preference of hypopi for dominant species of fleas, were presented by HaitLinger (1978) and PreisLer et al. (1990). However, the presence of these hypopi on the flea H. orientalis, as well as on the tick I. hexagonus, was not recorded so far.

Our results show that phoretic associations between fleas and mites can be common in Poland. So far, in Poland the phoresy of mites on fleas was noted in the Białowieża Forest and Owl Mountains (Góry Sowie) (Haitlinger 1978). It should also be stressed that this is the first report on phoretic associations of the flea H. orientalis and the tick I. hexagonus with mites.

Acknowledgements: This work was supported by the Ministry of Science and Higher Education, Warsaw, Poland (grants N308 017 31/1488 and N401 153 32/3010). 


\section{REFERENCES}

BaLashov Yu. S. 2006a. The origin and evolution of parasitism on terrestrial vertebrates in insects, mites, and ticks. Parazitologiia 40: 409-424.

BaLASHOV Yu. S. 2006b. Types of parasitism of acarines and insects on terrestrial vertebrates. Entomol. Rev. 86: 957-971.

BoczeK J., BŁaszaK C. 2005. Roztocze (Acari). Znaczenie w życiu i gospodarce człowieka [Mites (Acari). The importance in the human life and economy]. Wydawnictwo SGGW, Warszawa (in Polish).

BregEtova N. G. 1956. Gamazovye kleshchi (Gamasoidea) [Gamasid mites]. AN SSSR, Moskva - Leningrad (in Russian).

Bregetova I. G., Bulanova-Zakhvatkina E. M., Volgin V. I., Dubinin V. B., Zakhvatkin A. A., Zemskaja A. A., Lange A. B., Pavlovskij E. N., Serdiukova G. V., Shluger E. G. 1955. Kleshchi gryzunov fauny SSSR [Ticks of rodents of SU]. Akademija Nauk SSSR, Moskva, Leningrad (in Russian).

Britt D. P., Molyneux D. H. 1983. Phoretic associations between hypopi of Acarus nidicolous (Acari, Astigmata, Acaridae) and fleas of British small mammals. Ann. Parasit. Hum. Comp. 58: $95-98$.

Combes C. 1995. Interactions durables. Écologie et evolution du parasitisme. Masson, Editeur, Paris.

Dubinina H. V., Alekseev A. N. 1995. Mite hypopi on ticks. Acarina 3: 73-83.

DURDEN L. A. 1986. The reinfestation of forest rats (Maxomys musschenbroekii) by epifaunistic arthropods in Sulawesi. Indonesia J. Trop. Ecol. 2: 283-286.

FAIN A. 1987. Observation on the hypopi of the genus Forcellinia Oudemans, 1924 (Acari, Acaridae). Bull. Inst. R. Sci. Nat. Belg. Entomol. 57: 120.

Fain A., Beaucournu J. C. 1973. Deux nouveaux hypopes vivant en association phorétique sur des puces de carnivores (Acarina: Sarcoptiformes) [2 new hypopi living in phoretic association on the fleas of carnivors (Acarina: Sarcoptiformes)]. Acarologia 15: 138-143 (in French).

Fain A., Beaucournu J. C. 1993. The hypopi of the astigmatic mites (Acari) phoretic on the fleas (Siphonaptera) of mammals and birds. Bull. Inst. R. Sci. Nat. Belg. Entomol. 63: 77-93.

Fain A., Galloway T. D. 1993. Mites (Acari) from nests of sea birds in New Zealand. 1. Description and developmental stages of Psylloglyphus parapsyllus n.sp. (Winterschmidtiidae). Acarologia 34: 159-166.

Fain A., Whitaker J. O. 1985. Labidophorus nearcticus n.sp. (Astigmata: Labidophorinae) a new glycyphagid mite from Parascalops breweri in the United States. J. Parasitol. 71: 327-330.

Gilyarov M. S., KRIVolutSKIJ A. D. 1975. Opredelitel obitayushchikh v pochve kleshchej Sarcoptiformes [Key for the identification of soil mites Sarcoptiformes]. Izd. Nauka, Moskva (in Russian).

Griffiths D. A. 1970. A further systematic study of the genus Acarus L., 1758 (Acaridae, Acarina) with a key to species. Bull. Brit. Mus. Nat. Hist. Zool. 19: 85-126.

Haitlinger R. 1978. Occurrence in Poland of Acarus nidicolous Griffiths, 1970 (Acarina: Sarcoptiformes)-(Hypopus) associated with Siphonaptera. Wiad. Parazytol. 24: 491-493.

Haitlinger R. 1983. Invertebrates associated with the bank vole. Acta Theriol. 28 (suppl. 1): $55-68$.

Houck M. A., O'Connor B. M. 1991. Ecological and evolutionary significance of phoresy in the Astigmata. Ann. Rev. Entomol. 36: 611-636.

Hughes A. M. 1976. The mites of stored food and houses. H.M.S.O., London, UK

KarbowiaK G., Wita I. 2001. Zarażenie pchłami nornicy rudej Clethrionomys glareolus i myszy leśnej Apodemus flavicollis na Pojezierzu Mazurskim [The infestation of bank-vole Clethrionomys glareolus and yellow-necked mouse Apodemus flavicollis with fleas in the Mazurian 
Lakeland]. In: Stawonogi: pasożyty i nosiciele [Arthropods: parasites and hosts] (Buczek A., Błaszak Cz., Eds.), pp. 111-118, Wydawnictwo KGM, Lublin (in Polish).

Krantz G. W., Walter, D. E. 2009. A manual of acarology. Third edition. Texas Tech. University Press, Lubbock, USA.

LACHMAJER J., Wegner Z. 1956. Fauna pcheł i wszy pasożytujących na drobnych ssakach Białowieskiego Parku Narodowego [Fleas and lice parasitizing small mammals in the Białowieza National Park]. Wiad. Parazytol. 5 (suppl): 103-104 (in Polish).

Matthee S., Horak I. G., Beaucournu J. C., Durden L. A., Ueckermann E. A., Mc Geoch M. A. 2007. Epifaunistic arthropod parasites of the four-striped mouse, Rhabodomys pumilio, in the Western Cape Province, South Africa. J. Parasitol. 93: 42-59.

Pence D. B, Webi J. P. 1977. Notes on Hypopi of two Dermacarus species (Acari: Astigmata: Glycyphagidae) from the Douglas squirrel, Tamiasciurus douglasii. J. Med. Entomol. 14: 175-179.

Preisler J, SAmšiñák K, Černý V. 1990. First record of mite hypopi (Acaridae) on fleas from Czechoslovakia. Folia Parasitol. 37: 94.

Schwan T. G. 1993. Sex ratio and phoretic mites of fleas (Siphonaptera: Pulicidae and Hystrichopsyllidae) on the Nile grass rat (Arvicanthis niloticus) in Kenya. J. Med. Entomol. 30: 122-135.

Skuratowicz W. 1967. Klucze do oznaczania owadów Polski. T.XXIX. Pchły [Keys to insects of Poland. XXIX. Fleas]. PWN, Warszawa (in Polish).

STANKo M. 1988. Blchy (Siphonaptera) drobných zemných cicavcov východnej časti Volovských Vrchov (Slovenské Rudohorie) [Fleas of small mammals of eastern part of Volovec Mountains]. Zbor. Slov. nár. Múz., Prír. Vedy 34: 29-40 (in Slovak).

Szymkowiak P., Górski G., Bajerlein D. 2007. Passive dispersal in arachnids. Biological Lett. 44: 75-101.

Whitaker J. O. JR, Lyons E. A., Smith M. A., Maser C. 1983. Nest inhabitants and ectoparasites of northern flying squirrels, Glaucomys sabrinus (Shaw), from Northeastern Oregon. Northwest Sci. 57: 291-295.

Whitaker J. O. JR, Walters B. L., Castor L. K., Ritzi C. M., Wilson N. 2007. Host and distribution lists of mites (Acari), parasitic and phoretic, in the hair or on the skin of north american wild mammals north of Mexico: records since 1974. Faculty Publications from the Harold W. Manter Laboratory of Parasitology, University of Nebraska - Lincoln. 